\title{
Molecular detection of flaviviruses and alphaviruses in mosquitoes (Diptera: Culicidae) from coastal ecosystems in the Colombian Caribbean
}

\author{
Richard Hoyos-López¹/+, Juan Suaza-Vasco², Guillermo Rúa-Uribe ${ }^{3}$, \\ Sandra Uribe' ${ }^{2}$ Juan Carlos Gallego-Gómez ${ }^{1}$ \\ 'Universidad de Antioquia, Translational and Molecular Medicine Group, Medellín, Antioquia, Colombia \\ ${ }^{2}$ Universidad Nacional de Colombia, Grupo de Investigación en Sistemática Molecular, Medellín, Antioquia, Colombia \\ ${ }^{3}$ Universidad de Antioquia, Facultad de Medicina, Grupo de Entomología Médica, Medellín, Antioquia, Colombia
}

Arboviruses belonging to the genera Flavivirus and Alphavirus were detected in mosquitoes in a rural area of San Bernardo del Viento (Córdoba, Colombia). A total of 22,180 mosquitoes were collected, sorted into 2,102 pools, and tested by generic/nested reverse transcription-polymerase chain reaction. Venezuelan equine encephalitis virus, dengue virus, West Nile virus, St. Louis encephalitis virus, yellow fever virus, and Culex flavivirus were detected and identified by sequencing. The detection of arboviral pathogens in this zone represents possible circulation and indicates a human health risk, demonstrating the importance of virological surveillance activities.

Key words: alphavirus - flavivirus - mosquitoes - mangroves - emerging infectious diseases - molecular detection

The known mosquito-associated arboviruses in Colombia are found in three families and four genera of medically important viruses: Flaviviridae (Flavivirus), Togaviridae (Alphavirus), and Bunyaviridae (Orthobunyavirus and Phlebovirus) (Groot 1996, Weaver 2005). Representative pathogenic arboviruses associated with human illness in South America include the West Nile virus (WNV), dengue virus (DENV), Venezuelan equine encephalitis virus (VEEV), eastern equine encephalitis virus (EEEV), Saint Louis encephalitis virus (SLEV), yellow fever virus (YFV), Zika virus (ZIKV), and Chikungunya virus (CHIKV) (Gubler 2008, Weaver $\&$ Reisen 2010). Negeviruses represent another important group. These recently described viruses comprise insect-specific viruses found in mosquitoes and phlebotomine sandflies (Vasilakis et al. 2013, Auguste et al. 2014, Nunes et al. 2015).

There are historical reports of alphaviruses (VEEV, EEEV, Mayaro), flaviviruses (YFV, WNV, DENV, SLEV, Ilheus, Bussuquara), and bunyaviruses (Anopheles A, Anopheles B, Guaroa, Oya, Oropouche, Wyeomyia) in areas of the Magdalena river valley, Llanos Orientales, Gulf of Uraba, Guajira, Catatumbo, Caribbean, and Pacific coast of Colombia (Groot 1964, PríasLandínez et al. 1968, SanMartín et al. 1971, Rivas et al.

doi: 10.1590/0074-02760160096

Financial support: COLCIENCIAS (grant-111599326198 and convocatory 528, scholarships for PhD students).

+ Corresponding author: rhoyoslopez@gmail.com

Received 11 March 2016

Accepted 19 July 2016
1995, Weaver et al. 1996, 2004, Hastriter \& Lawyer 1998, Ferro et al. 2003, 2008, Méndez et al. 2003, Jaramillo et al. 2005, Mattar et al. 2005a, b, 2011, Álvarez et al. 2010, Góez-Rivillas et al. 2010, Múnera et al. 2010, Osorio et al. 2012, Barrera et al. 2015, Hoyos-López et al. 2015a, b, c). Moreover, mosquitoes in the genera Aedes, Anopheles, and Culex (including subgenera Culex and Melanoconion), and Haemagogus, and in the tribe Sabethini are recognised as potential vectors of such viruses (RocaGarcia 1944, Groot 1964, Ferro et al. 2003, 2008, Jaramillo et al. 2005). Continuous ecological change, including fragmentation of natural ecosystems, may increase the probability of human-vector contact (Hastriter \& Lawyer 1998, Ferro et al. 2015) and, consequently, the possibility of outbreaks of emerging and re-emerging arboviruses. Although some studies have focused on arbovirus detection in wild mosquito populations in Colombia, these reports are relatively scarce. This is despite efforts in the last few years to record potential vector mosquito species, to identify the vector species in recent arboviral outbreaks, and to validate molecular techniques for viral detection (Ferro et al. 2003, 2008, González-Reiche 2010, Parra-Henao \& Suárez 2012, Barajas et al. 2013, HoyosLópez et al. 2015a, b, c).

The present study provides an update on emerging and re-emerging arboviruses in Colombia, particularly for the Caribbean coastal zone and for flaviviruses and alphaviruses. Results were obtained as a part of a multidisciplinary study conducted between 2011-2013 in San Bernardo del Viento (Córdoba department, Colombia), an area poorly studied in terms of arboviruses, despite exhibiting particular conditions such as the presence of migratory birds and other fauna that might act as viral reservoirs and recent anthropogenic activities (fragmentation of mangrove forests, expansion of rice fields, and expansion of cattle ranching) that might promote the transmission of arboviruses to humans. 


\section{MATERIALS AND METHODS}

Study area and mosquito samples - Mosquitoes were collected at eight sites in a rural area called "La Balsa" $\left(9^{\circ}\right.$ $\left.21^{\prime} 30.97^{\prime \prime} \mathrm{N}, 75^{\circ} 58^{\prime} 37.28^{\prime \prime} \mathrm{W}\right)$ in San Bernardo del Viento (Fig. 1). San Bernardo del Viento (approximate population: 32,000 ) is two meters above sea level, has a mean annual temperature of $30^{\circ} \mathrm{C}$ and is bordered by the Sinú River delta. The study area consisted of numerous mangrove trees (across $74 \mathrm{ha}$ ), such as "Mangle rojo" (Rhizophora mangle), "Mangle bobo" (Laguncularia racemosa), "Zaragoza" (Conocarpus erectus), "Mangle negro" (Avicennia germinans), and "Mangle piñuelo" (Pelliciera rhizophorae), with a canopy averaging $24 \mathrm{~m}$ in height (Rojas \& Sierra-Correa 2010). The ground is well irrigated by streams transecting the study site that eventually form ponds and ditches. Small rice fields cultivated by local residents near their homes and inside the mangrove habitats were also inspected. Cattle, chickens, goats, horses, and donkeys were the most common peridomestic animals observed in farm areas close (within approximately $400 \mathrm{~m}$ ) to the mangroves. Mosquitoes, namely resting and engorged females, were manually sampled.

Adult mosquitoes were collected on seven field trips between September 2011 and October 2013, during seasons (February-April, September-November) of peak bird migration. Each field trip consisted of five to seven days of sampling. Mosquitoes were collected using eight dry ice-baited CDC light traps operated for a $14 \mathrm{~h}$ period from 5:00 p.m. to 7:00 a.m. The light traps were placed in the mangrove forest, in small rice fields inside this forest, at the edge of mangroves, in secondary forests, and in peridomestic sites (Fig. 2). Additionally, manual and electric aspirators were used during the day (9:00 a.m.4:00 p.m.) to collect mosquitoes in their resting sites.

After each collection, mosquitoes were sorted and pooled in the field using a cold table. Mosquitoes were pooled based on similar external morphological characteristics. Samples were stored in cryovials containing 1-50 specimens, placed in a liquid nitrogen tank, and transported to the insectary (Universidad Nacional de Colombia, Medellín). A reference mosquito collection that includes morphospecies identified during the field trips was established. Mosquitoes were mounted and identified using morphological keys (Lane \& Cerqueira 1942, Lane 1953, Cova-Garcia 1966, Bram 1967, Arnell 1973, Berlin \& Belkin 1980, Sirivanakarn 1982, Clark-Gil \& Darsie Jr 1983, Pecor et al. 1992, Forattini 2002a, González \& Carrejo 2007). In addition, a barcoding methodology was used to identify mosquitoes (Kumar et al 2007, HoyosLópez et al. 2015a, b, c, d). Protocols were implemented as described in the International Barcode of Life (iBOL) project (http://www.ibol.org/).

Arbovirus detection by reverse-transcription polymerase chain reaction (RT-PCR) and sequencing - Each mosquito pool tested for viruses was triturated in a cold mortar with sterile minimum essential medium (MEM) supplemented with $10 \%$ foetal bovine serum and $1 \%$ penicillin and then clarified by centrifugation at 13000

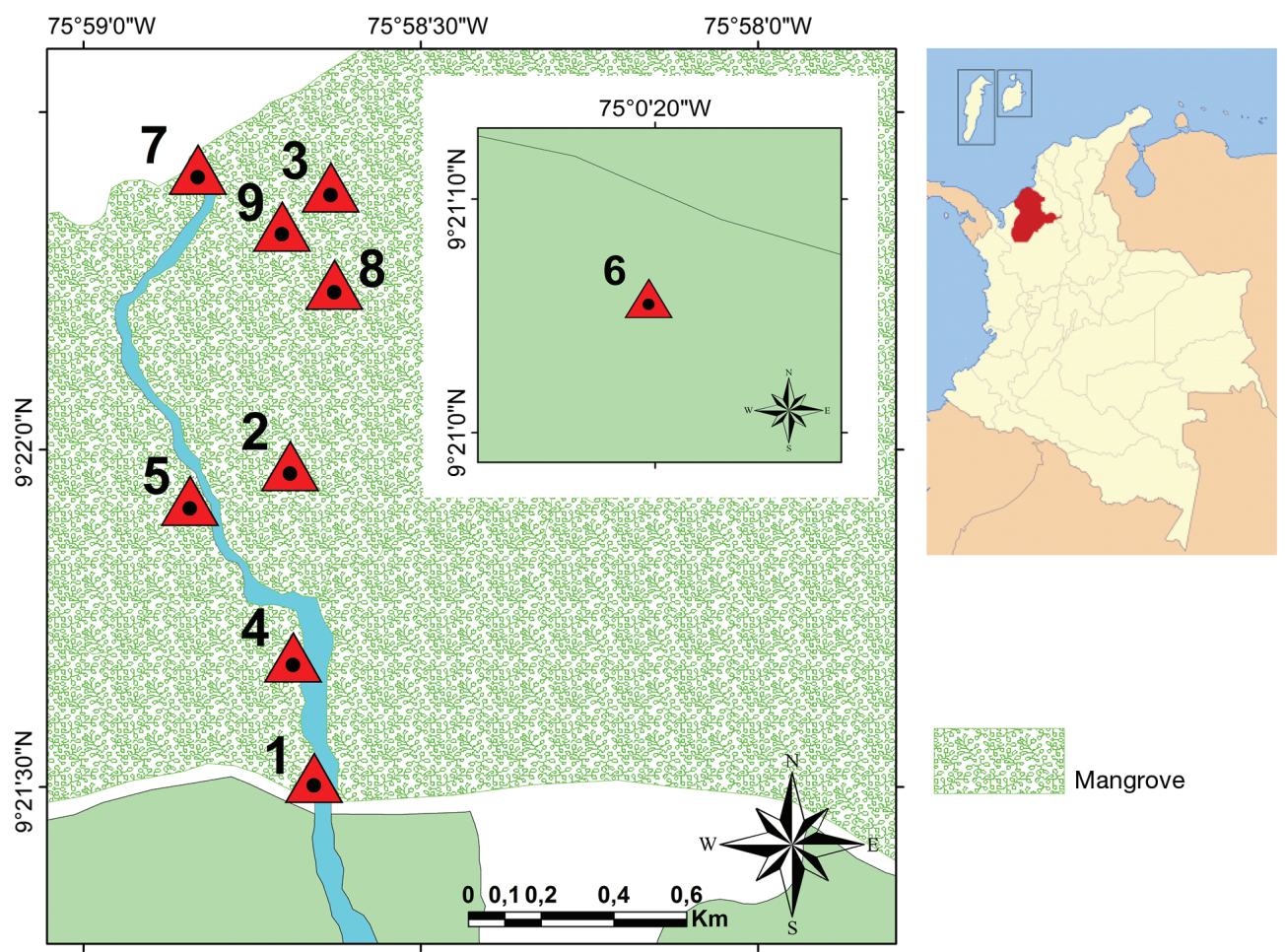

Fig. 1: map of the study area in San Bernardo del Viento (Córdoba). Precise sampling locations: (1) human domiciles in "La Balsa"; (4) pastures; (2) rice fields in mangrove forest; (3), (5), (7), (9), (8) mangrove forests; (6) secondary forest. The distance between the secondary forest and the rural zone "La Balsa" is $7.36 \mathrm{~km}$. 


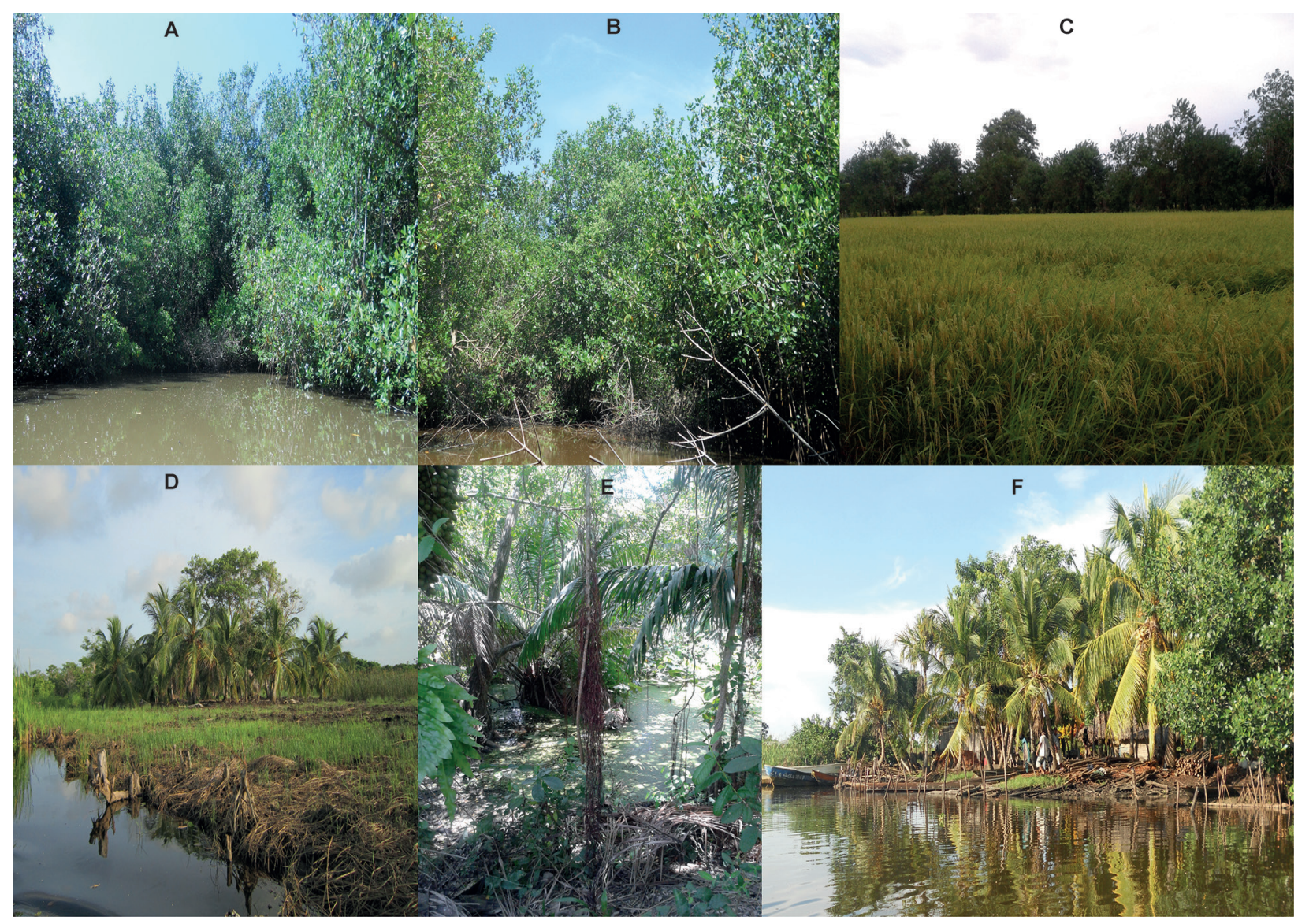

Fig. 2: ecosystems sampled in San Bernardo del Viento (Córdoba). (A-B) Mangrove forest; (C) rice fields in mangrove forest; (D) pastures; (E) secondary forest; (F) houses around mangroves (approximately $500 \mathrm{~m}$ ).

$\mathrm{rpm}$ for $30 \mathrm{~min}$. The supernatant was poured into Eppendorf tubes, and total RNA was extracted using an RNeasy Kit (Qiagen, Valencia, CA, USA). Generic (RT-PCR) and nested (RT-nested PCR) were performed using a One-Step RT-PCR kit (Qiagen, Valencia). The protocols used for flavivirus and alphavirus detection were those described by Sánchez-Seco et al. (2001, 2005) (Supplementary data, Table). The viruses used as positive controls were DENV (New Guinea strain) and VEEV (Argentina strain) donated by Dr Luis Adrián Díaz (Universidad Nacional de Córdoba). Positive samples were sequenced in both directions using an ABI automatic sequencer (Macrogen, Korea), and the resulting sequences were compared with GenBank reference sequences.

Sequence and data analyses - Nucleotide sequences of positive samples were compared with those of reference strains from each viral group (Sánchez-Seco et al. 2001, 2005). Sequences obtained from the first product amplified by RT-PCR (Sánchez-Seco et al. 2005) were aligned using Bioedit v7.0 (Hall 1999). The neighbour-joining algorithm (Saitou \& Nei 1987) and Kimura 2-parameter model (Nei \& Kumar 2000) were used to construct a dendrogram in MEGA v6.0 software (Tamura et al. 2013). Sequences were compared with those available from GenBank using BLASTN (Altschul et al.
1997). Minimum infection rates (MIRs) were calculated as follows: MIR $=$ number of positive pools by morphospecies/total number of morphospecies tested from that site $\times 1000$ (Walter et al. 1980).

Ethics - Mosquitoes were collected according to the guidelines of Colombian decree number 1376 (2013), which regulates the collection of wild specimens of biological diversity for non-commercial research. No specific permits were required for this study.

\section{RESULTS}

A total of 2102 pools, representing 14 morphospecies, were screened. Mosquitoes were identified based on morphology and DNA barcoding. A total of 268 voucher specimens of mosquito species were deposited in the Francisco Luis Gallego Entomological Museum.

Sequences from alphaviruses and flaviviruses were amplified from 30 of the 2102 mosquito pools (1.43\%) (Table). Mosquitoes belonging to the genus Culex according to morphology were collected most frequently. Deinocerites (De. atlanticus aff.), which were present in mangrove forests with numerous crab holes, were also common.

DNA barcodes were obtained for mosquitoes in the genus Culex; however, closely related species within the subgenera Culex and Melanoconion could not be distin- 
TABLE

Morphospecies, pools tested, viruses detected, and minimum infection rates (MIRs) by mosquito species

\begin{tabular}{|c|c|c|c|c|}
\hline Mosquito species & Mosquito tested & Pools tested & $\begin{array}{l}\text { Arboviruses identified } \\
\text { in positive pools }\end{array}$ & MIR* \\
\hline Culex spp. & 10011 & 816 & $\begin{array}{l}\text { VEEV (8) } \\
\text { SLEV (1) } \\
\text { WNV (2) } \\
\text { CxFv (2) }\end{array}$ & $\begin{array}{l}0.799 \\
0.099 \\
0.199 \\
0.199\end{array}$ \\
\hline Deinocerites atlanticus aff. & 6015 & 582 & VEEV (2) & 0.332 \\
\hline Mansonia titillans & 1887 & 259 & $\begin{array}{l}\text { VEEV (3) } \\
\text { SLEV (1) }\end{array}$ & $\begin{array}{c}1.59 \\
0.529\end{array}$ \\
\hline Aedes (Stegomyia) aegypti & 1150 & 107 & DENV2 (4) & 3.47 \\
\hline Culex (Culex) quinquefasciatus & 1019 & 99 & CxFv (4) & 3.92 \\
\hline Haemagogus sp. (Splendens section) & 757 & 78 & YFV (1) & 1.32 \\
\hline Psorophora (Grabhamia) confinnis & 622 & 71 & VEEV (1) & 1.61 \\
\hline Aedes scapularis & 512 & 62 & VEEV (1) & 1.95 \\
\hline Aedeomyia squamipennis & 83 & 11 & - & - \\
\hline Ochlerotatus taeniorhynchus & 72 & 9 & - & - \\
\hline Anopheles aquasalis & 35 & 5 & - & - \\
\hline Anopheles neomaculipalpus & 17 & 3 & - & - \\
\hline Total & 22180 & 2102 & $6(30)$ & - \\
\hline
\end{tabular}

*: MIR per 1000 mosquitoes. VEEV (Venezuelan equine encephalitis virus); SLEV (St. Louis encephalitis virus); WNV (West Nile virus); CxFV (Culex flavivirus); YFV (yellow fever virus); and DENV (dengue virus).

guished by their sequences, and an exact species could not be assigned to specimens other than $C x$. (Culex) quinquefasciatus (KT766432-KT766453).

Nested RT-PCR was used to identify viruses in mosquito pools. However, generic RT-PCR with primers targeting flaviviruses (1.1 kb, NS5 gene) and alphaviruses (500 b, nsP4 gene) were also obtained and sequenced, for consensus alignments of 515 and $420 \mathrm{nt}$, respectively. These sequences were used for identification by BLASTN search and neighbour-joining dendrograms.

The alphaviruses detected in pools of Culex spp., De. atlanticus aff., Mansonia titillans, Psorophora confinnis, and Aedes scapularis were all identified by their sequences as VEEV (GenBank accession numbers KM031058-KM031073) (Fig. 3). The flaviviruses were identified as DENV serotype 2 (DENV2) (Ae. aegypti), YFV (Haemagogus splendens), SLEV (Ma. titillans, Culex spp.), WNV (Culex spp.), and CxFV (Culex spp., Cx. quinquefasciatus) (Fig. 4) (GenBank accession numbers KM031074-KM031087). CxFV was the most commonly detected flavivirus (GenBank accession numbers KM031073-KM031078).

The MIR of SLEV, YFV, and WNV calculated for each morphospecies was low; the notable exceptions were CxFV in Cx. quinquefasciatus and DENV2 in Ae. aegypti. VEEV was detected in several mosquito species (Table).

VEEV was mostly detected in mosquitoes collected in mangrove forests or in neighbouring ecosystems (mangrove edge, 11 pools; rice crops in mangrove forest, six pools; and mangrove forest, five pools). SLEV, WNV, and YFV were detected only in mangroves. DENV2 was present in peridomestic sites, and CxFV was only detected in secondary forests.

\section{DISCUSSION}

The presence of five arboviruses (genera Alphavirus and Flavivirus) indicates the risk for emergence or re-emergence of these pathogens in San Bernardo del Viento.

The only alphavirus detected was VEEV, which was found in Culex spp., Ps. confinnis, De. atlanticus aff., Ae. scapularis, and Ma. titillans specimens. The frequency of VEEV detection and the number of mosquito morphospecies found infected with the virus may facilitate its transmission to reservoirs and possibly to humans (Ferro et al. 2003, 2015, Weaver et al. 2004). In Colombia, VEEV epidemics have been documented in various regions (Soriano-Lleras \& Figueroa 1942, Sanmartin-Barbieri \& Osorno-Mesa 1954, SanMartín et al. 1971, Rivas et al. 1995, Ferro et al. 2008, 2015), with the following mosquito species implicated in transmission: Ma. venezuelensis, Ae. serratus, Aedes (Ochlerotatus) spp., Ae. fulvus, and Culex (Melanoconion) spp. (Groot 1996, Weaver et al. 2004).

Many VEEV isolates have been obtained previously from the Magdalena valley (Ferro et al. 2003) and Norte de Santander (Ferro et al. 2008). In addition, Culex (Melanoconion) spp. infected with VEEV have been found in other localities in Colombia, such as Rionegro, Puerto Boyacá, and presumably Lozanía, Tolima; Cx. (Melanoconion) aikenii (syn. Cx. (Melanoconion) ocossa 


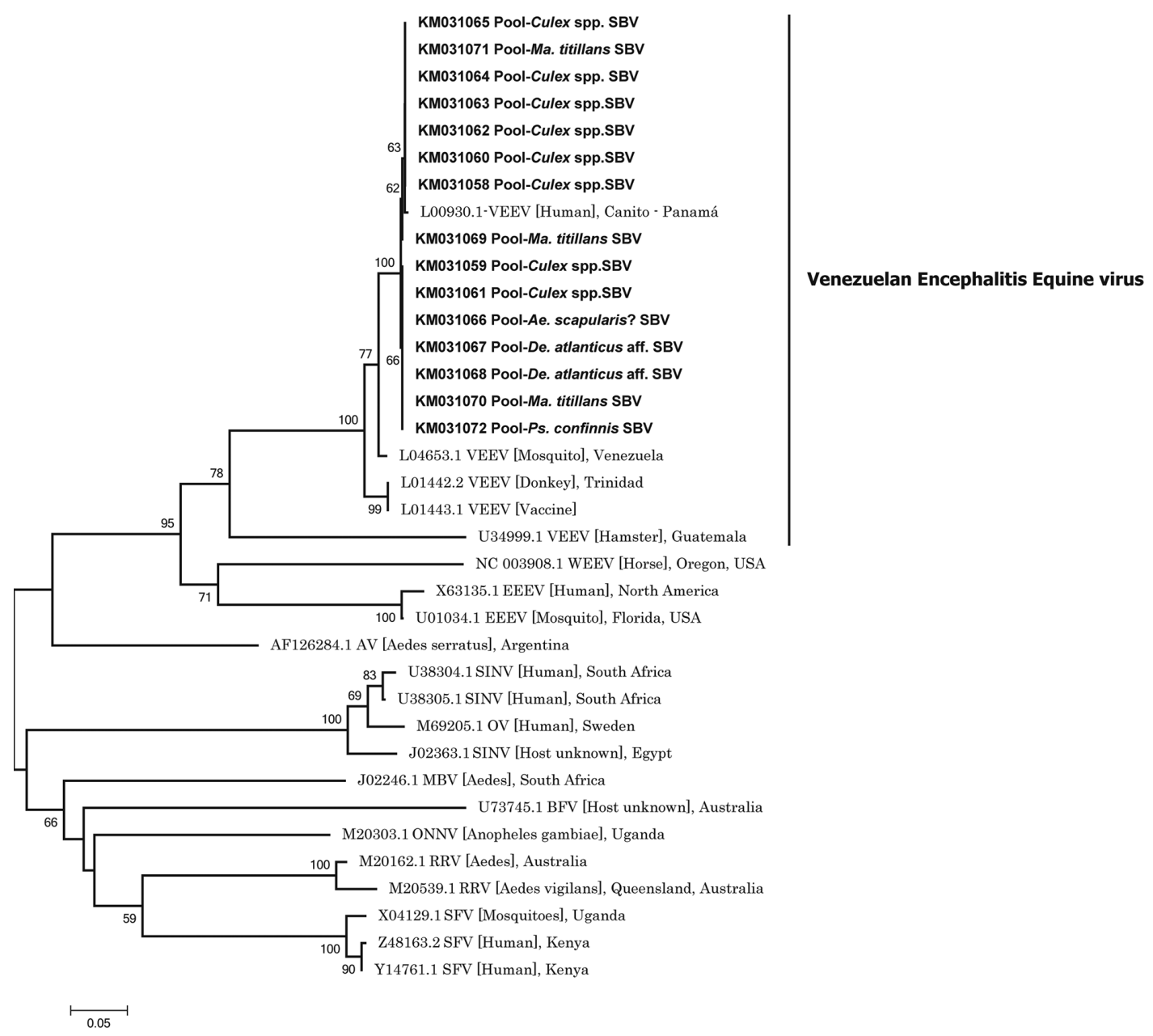

Fig. 3: neighbour-joining analysis used to identify Alphavirus sequences detected in mosquitoes (420 nt, nSP4). A dendrogram was constructed using representative sequences from the Alphavirus genus available in GenBank. The sequences detected were similar to representative Venezuelan equine encephalitis virus (VEEV) sequences. Abbreviations: WEEV (Western equine encephalitis virus); EEEV (Eastern equine encephalitis virus); AV (Aura virus); SINV (Sindbis virus); OV (Ockelbo virus); BFV (Barmah Forest virus); MBV (Middelburg virus); ONNV (o'nyong nyong virus); RRV (Ross River virus); and SFV (Semliki Forest virus). GenBank accession numbers are followed by the abbreviated names of viruses. The sequences of arboviruses detected in this study are presented with a GenBank accession number, followed by the mosquito species in which they were detected (in bold). SBV: San Bernardo del Viento, Córdoba (Colombia).

and $C x$. (Melanoconion) panocossa) were determined to be responsible for an epidemic of VEEV in 1973 (Groot 1964). Other species that have been reported as VEEV infected include Cx. (Melanoconion) vomerifer, $C x$. (Melanoconion) pedroi, and Cx. (Melanoconion) adamesi in the Monte San Miguel forest in the middle Magdalena valley (Ferro et al. 2008). Most strains of VEEV isolated from the Culex subgenus Melanoconion in Colombia have been categorized as enzootic subtype ID (Weaver et al. 1996, 2004). Our sequences grouped with VEEV subtype ID strain 3880, which was isolated from a human case in Canito, Panama (Brault et al. 2002). Parra-Henao and Suárez (2012) reported the presence of some Melanoconion species, including $C x$. (Mel.) erraticus, Cx. (Mel.) pedroi, and Cx. (Mel.) taeniopus, that were the first mosquito species identified by both, morphology and DNA barcoding, in an area adjacent to San Bernardo del Viento (Hoyos-López et al. 2015a, b). However, Cytochrome Oxidase I or DNA-bar- code fragment - COI sequences from specimens of the Culex subgenera Melanoconion and Culex did not allow molecular differentiation between these species, similar to that reported for species Cx. coronator in the subgenus Culex in Colombia (Rozo-Lopez \& Mengual 2015, Hoyos-López et al. 2015d), Cx. tarsalis and Cx. coronator in Brazil and Argentina (Laurito et al. 2013), and $C x$. salinarius in Brazil (Demari-Silva et al. 2011).

In our study, Culex spp., Ps. confinnis, Ae. scapularis, and Ma. titillans were found to be infected with VEEV. These species are likely enzootic vectors of the virus, as has been reported in various geographic regions of Colombia and in nearby countries (Groot 1964, Hastriter \& Lawyer 1998); however, the local vector status of these four species is unknown. Our study is the first report of a natural VEEV infection in De. atlanticus aff. This morphospecies was associated with crab holes in mangroves forests that are near the beach and in coconut groves. The adults of this species are reported to have nocturnal 


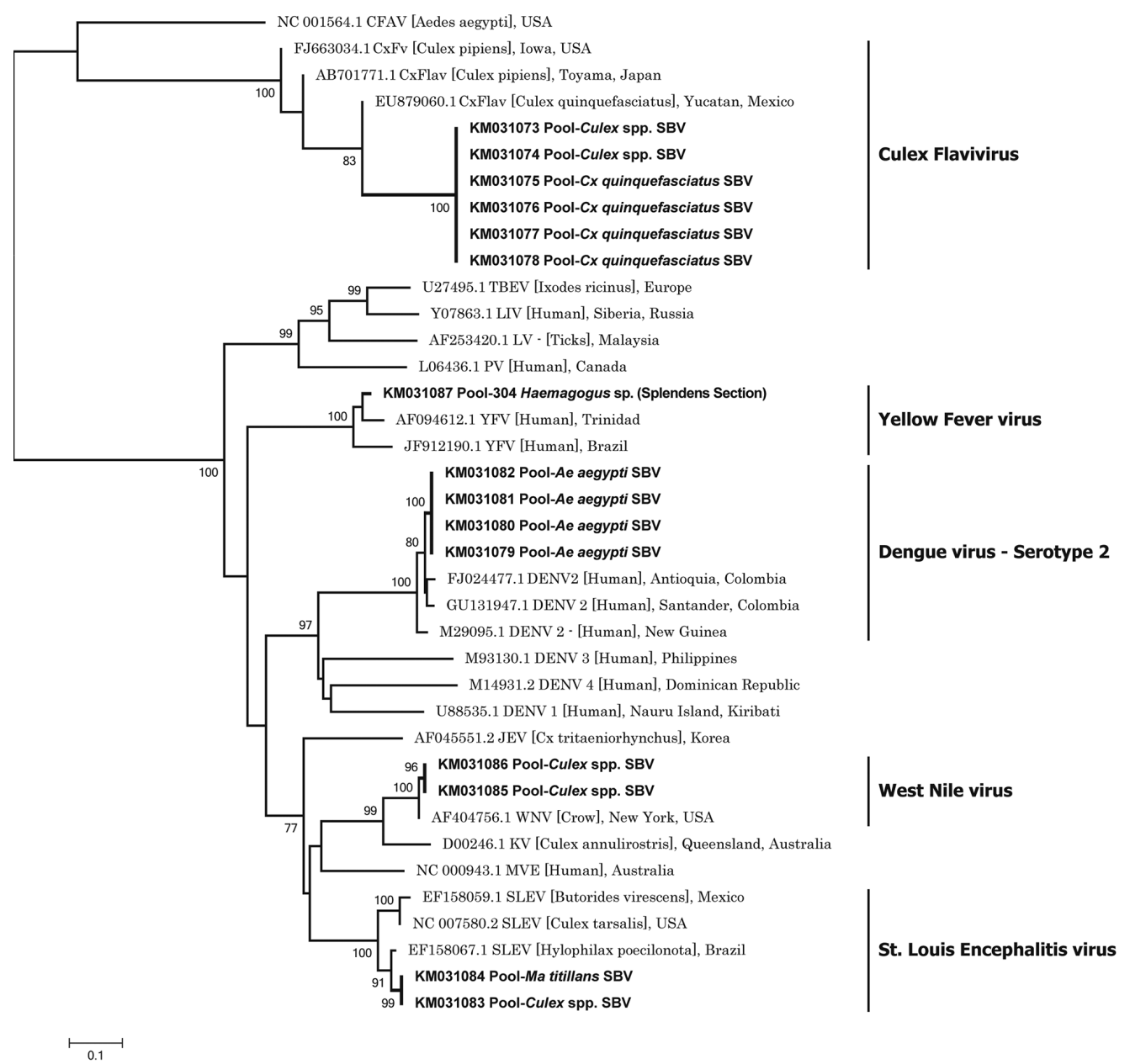

Fig. 4: neighbour-joining analysis used to identify Flavivirus sequences detected in mosquitoes (515 nt, NS5). A dendrogram was constructed using representative sequences of the Flavivirus genus available in GenBank. The sequences detected were similar representative sequences of dengue virus serotype 2 (DENV2), yellow fever virus (YFV), West Nile virus (WNV), St. Louis encephalitis virus (SLEV), and Culex flavivirus (CxFV). Abbreviations: PV (Powassan virus); LV (Langat virus); LIV (louping ill virus); TBEV (tick-borne encephalitis virus); KV (Kunjin virus); MVE (Murray Valley virus); JEV (Japanese encephalitis virus); CFAV (cell fusing agent virus). GenBank accession numbers are followed by the abbreviated names of viruses. The sequences of arboviruses detected in this study are presented with a GenBank accession number, followed by the mosquito species in which they were detected (in bold). SBV: San Bernardo del Viento, Córdoba (Colombia).

or crepuscular habits, resting by day in the upper parts of crab holes (Belkin \& Hogue 1959). Their biting activity may extend to humans (Adames 1971). However, many essential aspects of De. atlanticus aff. biology remain unknown. In the Guajira department, De. atlanticus aff. is the dominant mosquito species. It has been collected inside houses and is a vector of VEEV in this geographic area (Ferro et al. 2015).

SLEV and WNV are emerging flaviviruses that have been detected previously in humans, equines, and birds in the Colombian Caribbean region (Mattar et al. 2005a, b, 2011, Goéz-Rivillas et al. 2010, Osorio et al. 2012). Both viruses detected in this study were molecularly characterised based on the NS5 and envelope genes and were found to be closely related to genotypes associated with attenuated virulence (WNV Texas genotype) (Hoyos-López et al. 2015a) and little activity in human populations (SLEV genotype IV) (Hoyos-López et al. 2015b).

The CxFV detected in this study in pools of Cx. quin- quefasciatus is the first evidence of this virus in Colombia, although it has been reported in the same species in other countries (Hoshino et al. 2007, Morales-Betoulle et al. 2008, Cook et al. 2009, Farfan-Ale et al. 2009, Kim et al. 2009, Huanyu et al. 2012, Machado et al. 2012). A strong ecological association between $\mathrm{CxFV}$ and WNV was observed in Chicago, USA (Newman et al. 2011), suggesting that super-infection with WNV during CxFV infection may interfere with secondary viral infection with a similar virus (Farfan-Ale et al. 2009). However, experimental infections of $C x$. quinquefasciatus with WNV strain Guatemala and CxFV strain Izabal do not support this hypothesis, because prior infection with CxFV had no significant impact on WNV replication, infection, dissemination, or transmission by this mosquito (Kent et al. 2010). It is possible that natural infection with CxFV affects the vector competence of $C x$. quinquefasciatus through vertical transmission and persistence in mosquito progeny (Bolling et al. 2012), in- 
fluencing the ecology of viruses such as WNV and SLEV and even enhancing WNV transmission (Kent et al. 2010). Interestingly, $C x$. quinquefasciatus was collected only in secondary forests and was absent from peridomestic areas. Possible explanations include the low density (approximately 30) of human households close to mangroves, saline water, and availability of few breeding sites (Forattini et al. 2002b, Correia et al. 2012). Potential breeding sites (many ponds and livestock watering devices) were found near the forest collection site.

In Colombia, vectors that participate in sylvatic YFV transmission include Haemagogus equinus and Haemagogus janthinomys (Morales 1968). Natural infection of Haemagogus sp. (Splendens section) with YFV may suggest an epidemiological risk for humans working in mangroves, as this species readily bites humans and is present in high densities in coastal mangrove forests (Arnell 1973). There have been previous reports of experimental and natural infection of YFV (Galindo et al. 1956, de Rodaniche et al. 1957) and SLEV in Haemagogus from Panamá (Kramer \& Chandler 2001). In San Bernardo del Viento, cases of yellow fever have not been recorded; however, they are reported annually in the Caribbean region of the Cesar, Guajira, and Magdalena departments (Rojas-Álvarez 2008).

DENV2, and predominantly the American/Asian genotype (subtype IIIb), is frequently detected in patients in Colombia (Méndez et al. 2012). Although there are few cases in San Bernardo del Viento, with approximately 4-6 patients reported between 2011 and 2014 (Secretaría de Salud Municipal, San Bernardo del Viento, personal communication), asymptomatic human cases and clinical underreporting is likely common in other regions of Colombia (Méndez et al. 2006).

We report the first detection of flaviviruses and alphaviruses circulating in coastal mangroves and neighbouring ecosystems in Colombia, indicating a potential health risk to humans living or working in these zones. Interestingly, in the present study, the mangrove edge harboured the most positive pools of VEEV. Some authors have suggested an important role for the transitional zone between two adjacent ecological systems (e.g., mangroves and pastures) or "ecotones" in the transmission of emerging viruses and arboviruses (Estrada-Franco et al. 2004, Despommier et al. 2006). Mosquitoes that vector several viruses (i.e., Rift Valley fever, VEEV, YFV) have been found to be abundant in ecotones (Olival \& Daszak 2005, Despommier et al. 2006), and they may have the potential to adapt and exploit new breeding sites in human-dominated ecosystems (Diallo et al. 2012). The presence of Culex subgenera Melanoconion and Culex may be important to the emergence and/or re-emergence of WNV, SLEV, and VEEV. Mangrove ecosystems, may be specifically acting as a source of emerging pathogens that infect nearby human populations (Holmes 2008). Furthermore, ecotones have been identified as potentially important for host seeking and host switching (Burg 2001, Méndez et al. 2001, Hoberg et al. 2002). Because of the high concentrations of reservoirs and potential hosts, jumps to alternative hosts or mosquitos with different levels of vector competence may be favoured (Barrera et al. 2002, Deardoff et al.
2011). A key factor is that RNA arboviruses have high rates of evolution that may facilitate the generation of progeny with variable fitness or virulence in alternative hosts (Holmes 2008, 2009, Hoyos et al. 2012).

All of these ecological and evolutionary factors may play a role in niche changes and consequent "jumps" of new pathogens to humans (Weaver 2005, Despommier et al. 2006, Holmes 2008, 2009, Hoyos et al. 2012). Therefore, it will be important to further study some aspects of arbovirus ecology in San Bernardo del Viento, such as the diversity of possible reservoirs, including migrant/resident birds, rodents, opossums, and bats. The wildlife commonly associated with mangrove forests around "La Balsa" include 296 species of birds (belonging to 61 families, of which 64 species are migratory) (Estela et al. 2005, 2010, Arzuza et al. 2008, Ruiz-Guerra et al. 2008), reptiles (Rojas \& Sierra-Correa 2010), and mammals such as rodents (Oligoryzomys spp. and Zygodontomys spp.), bats (Artibeus spp., Carollia spp., and Sturnira spp.), sloths (Bradypus spp.), opossums (Didelphis marsupialis) (unpublished data), and primates (Aotus lemurinus, Ateles geoffroyi, Cebus albifrons, and Saguinus oedipus) (Rojas \& Sierra-Correa 2010). Other factors such as the spatial distributions of potential reservoirs, arboviruses present in these communities, and evolutionary variants (e.g., low virulence) of detected arboviruses may explain the absence of encephalitis/haemorrhagic fever cases in humans (Mattar et al. 2005b, Weaver 2005, Hoyos-López et al. 2015a, b).

Arbovirus detection is just one aspect of vector incrimination, and more data are needed to identify potential vectors, define vector competence, and identify specific habitats, biting behaviour, and blood feeding patterns of possible vectors. All of these aspects should be considered in a context of global climate change, which is another factor that may contribute to the emergence of new diseases (Naicker 2011, Butler 2012) and may be particularly important in Colombia, which experiences the effects of climatological oscillations such as ENSO (Poveda et al. 2001, Singh 2013). These abiotic changes may contribute to an increase in the size of mosquito populations and in cases of vector borne diseases (Poveda et al. 2000). These perspectives may contribute to the development of more effective disease prevention and control strategies.

\section{ACKNOWLEDGEMENTS}

To Dr Luis Adrián Díaz, of the Universidad Nacional de Córdoba (Córdoba, Argentina), for his collaboration in the methodological design and advice for exploratory field trips, Diego León Arias, Diego Carrero Sarmiento, Maria Angelica Contreras and undergraduate students Diego Puerta and David Gallo, for their assistance in entomological collections.

\section{REFERENCES}

Adames A. A revision of the crabhole mosquitoes of the genus Deinocerites. Contrib Am Entomol Inst. 1971; 7(2): 1-158.

Altschul SF, Madden TL, Schaffer AA, Zhang J, Zhang Z, Miller W, et al. Gapped BLAST and PSI-BLAST: a new generation of protein database search programs. Nucleic Acids Res. 1997; 25(17): 3389-3402. 
Álvarez J, González M, Mattar S. Actividad del virus del oeste del Nilo y otros flavivirus en cinco departamentos del Caribe colombiano. Rev MVZ Córdoba. 2010; 15(1): 2021-2.

Arnell JH. Mosquito studies (Diptera:Culicidae) XXXII. A revision of the genus Haemagogus. Contrib Amer Entomol Inst. 1973; 10(2): 1-174.

Arzuza D, Moreno M, Salaman P. Conservación de las aves acuáticas de Colombia. Conservación Colombiana. 2008; 6: 1-72.

Auguste AJ, Carrington CV, Forrester NL, Popov VL, Guzman H, Widen SG, et al. Characterization of a novel Negevirus and a novel Bunyavirus isolated from Culex (Culex) declarator mosquitoes in Trinidad. J Gen Virol. 2014; 95(2): 481-5.

Barajas J, Suaza J, Torres C, Rúa G, Uribe-Soto S, Porter C. Mosquitos (Diptera: Culicidae) asociados a guadua en los municipios de Anserma, Hispania y Jardín, Colombia. Rev Col Entomol. 2013; 39(1): $132-40$.

Barrera R, Ferro C, Navarro J, Freier J, Liria J, Salas R, et al. Contrasting sylvatic foci of Venezuelan equine encephalitis virus in northern South America. Am J Trop Med Hyg. 2002; 67(3): 324-34.

Barrera S, Martinez S, Tique-Salleg V, Miranda J, Guzman C, Mattar S. Seroprevalencia de Hantavirus, Rickettsia y Chikungunya en población indígena del municipio de Tuchín, Córdoba. Infectio. 2015; 19(2): 75-82

Belkin J, Hogue C. A Review of the crabhole mosquitoes of the genus Deinocerites (Diptera, Culicidae). Univ Calif Pubs Entomol. 1959; 14(6): 411-58.

Berlin O, Belkin J. Mosquito studies (Diptera: Culicidae). XXXVI. Subgenera Aedinus, Tinolestes and Anoedioporpa of Culex. Contrib Amer Entomol Inst. 1980; 17(2): 1-104.

Bolling BG, Olca-Popelka FJ, Eisen L, Moore CG, Blair CD. Transmission dynamics of an insect-specific flavivirus in a naturally infected Culex pipiens laboratory colony and effects of co-infection on vector competence for West Nile virus. Virology. 2012; 427(2): 90-7.

Bram RA. Classification of Culex subgenus Culex in the New World (Diptera, Culicidae). Proceedings of United States Natural History Museum. 1967; 120(3557): 1-122.

Brault AC, Powers AM, Holmes EC, Woelk CH, Weaver SC. Positively charged amino acid substitutions in the E2 envelope glycoprotein are associated with the emergence of Venezuelan equine encephalitis virus. J Virol. 2002; 76(4): 1718-30.

Burg J. Seasonal activity and spatial distribution of host-seeking adults of the tick Dermacentor variabilis. Med Vet Entomol. 2001; 15(4): 413-21.

Butler C. Infectious disease emergence and global change: thinking systemically in a shrinking world. Infect Dis Poverty. 2012; 1(1): 5.

Clark-Gil S, Darsie Jr RF. The mosquitoes of Guatemala. Their identification, distribution and bionomics. Mosq Syst. 1983; 15(3): 151-284.

Cook S, Moureau G, Harbach R, Mukwaya L, Goodger K, Ssenfuka $\mathrm{F}$, et al. Isolation of a novel species of flavivirus and a new strain of Culex Flavivirus (Flaviviridae) from a natural mosquito population in Uganda. J Gen Virol. 2009; 90(11): 1669-78.

Correia JC, Barbosa RMR, de Oliveira CMF, de Albuquerque CMR. Residential characteristics aggravating infestation by Culex quinquefasciatus in a region of Northeastern Brazil. Rev Saude Publica. 2012; 46(6): 935-41.

Cova-García P. Mosquitos de Venezuela. Tomo II. Caracas: Ministerio de Sanidad y Asistencia Social; 1966. 66 pp.

de Rodaniche E, Galindo P, Johnson C. Isolation of yellow fever virus from Haemagogus lucifer, H. equinus, $H$. spegazzinii falco, $\mathrm{Sa}$ - bethes chloropterus and Anopheles neivai captured in Panama in the fall of 1956. Am J Trop Med Hyg. 1957; 6(4): 681-5.

Deardoff E, Estrada-Franco J, Freier J, Navarro-López R, da Rosa A, Tesh R, et al. Candidate vectors and rodent hosts of Venezuelan equine encephalitis virus, Chiapas, 2006-2007. Am J Trop Med Hyg. 2011; 85(6): 1146-53.

Demari-Silva B, Vesqueiro FT, Sallum MA, Marelli MT. Taxonomic and phylogenetic relationships between species of the genus Culex (Diptera: Culicidae) from Brazil inferred from the cytochrome c oxidase I mitochondrial gene. J Med Entomol. 2011; 48(2): 272-9.

Despommier D, Ellis B, Wilcox B. The role of ecotones in emerging infectious diseases. EcoHealth. 2006; 3(4): 281-9.

Diallo D, Diagne CT, Hanley KA, Sall AA, Buenemann M, Ba Y, et al. Larval ecology of mosquitoes in sylvatic arbovirus foci in southeastern Senegal. Parasit Vectors. 2012; 5: 286.

Estela F, López-Victoria M. Aves de la parte baja del Rio Sinú, Caribe Colombiano; inventario y ampliaciones de distribución. Bol Invest Mar Cost. 2005; 34(1): 7-42.

Estela F, Ruiz-Guerra C, Solano O, Ortiz-Ruiz J. Aves del estuario del Río Sinú. Cali: Asociación Calidris; 2010. 34 pp.

Estrada-Franco JG, Navarro-López R, Freier J, Cordova D, Clements T, Moncayo A, et al. Venezuelan equine encephalitis virus, Southern Mexico. Emerg Infect Dis. 2004; 10(12): 2113-21.

Farfan-Ale J, Loroño-Pino M, Garcia-Rejon J, Hovav E, Powers A, Lin M, et al. Detection of RNA from a novel West Nile-like virus in high prevalence of an insect-specific flavivirus in mosquitoes in the Yucatan Peninsula of Mexico. Am J Trop Med Hyg. 2009; 80(1): 85-95.

Ferro C, Boshell J, Moncayo A, González M, Ahumada M, Kang W, Weaver S. Natural Enzootic vectors of Venezuelan equine encephalitis virus in the Magdalena Valley, Colombia. Emerg Infect Dis. 2003; 9(1): 49-54.

Ferro C, de las Salas J, González M, Díaz A, Cabrera C, Flórez Z, et al. Do some conditions contribute to the reemergence of the Venezuelan equine encephalitis virus in the Colombian Alta Guajira? Biomédica. 2015; 35(1): 62-72.

Ferro C, Olano V, Ahumada M, Weaver S. Mosquitos (Diptera: Culicidae) en el caserio de Chingalé, Santander, donde se registró un caso humano de encefalitis equina venezolana. Biomedica. 2008; 28(2): 234-44.

Forattini O. Culicidologia médica: identificação, biología, epidemiología. Vol. II. São Paulo: Universidad de São Paulo; 2002a. 859 pp.

Forattini OP, Kakitani I, Santos RLC, Kobayashi KM, Ueno HM, Fernandez Z. Potencial sinantrópico de mosquitos Kertezia e Culex (Diptera: Culicidae) no Sudeste do Brasil. Rev Saude Publica. 2002b; 34(6): 565-9.

Galindo P, de Rodaniche E, Trapido H. Experimental transmission of yellow fever by Central American species of Haemagogus and Sabethes chloropterus. Am J Trop Med Hyg. 1956; 5(6): 1022-31.

Góez-Rivillas Y, Taborda N, Díaz F, Góngora A, Rodas J, Ruiz-Sáenz $\mathrm{J}$, et al. Antibodies to West Nile virus in equines of Antioquia and Meta, Colombia, 2005-2008. Rev Colomb Cienc Pecu. 2010; 23(4): 462-4.

González R, Carrejo N. Introducción al estudio taxonómico de Anopheles de Colombia. Claves y notas de distribución. Grupo de Investigaciones Entomológicas. Colombia: Universidad del Valle; 2007. 238 pp.

González-Reiche A, Monzón-Pineda M, Johnson B, Morales-Betoulle M. Detection of West Nile viral RNA from field-collected mosquitoes in tropical regions by conventional and real-time RTPCR. Methods Mol Biol. 2010; 630: 109-24. 
Groot H. Estudios sobre virus transmitidos por artrópodos en Colombia. Rev Acad Colomb Cienc. 1964; XII(46): 197-217.

Groot H. Estudios de arbovirosis en Colombia en la década de 1970. Biomedica. 1996; 16(4): 331-44.

Gubler D. The global threat of emergent/reemergent vector-borne siseases. In: Lemon S, Sparling F, Hamburg M, Relman D, Choffnes E, Mack A, editors. Vector-borne diseases: understanding the environmental, human health, and ecological connections, workshop summary (Forum on Microbial Threats). Washington (DC): National Academy of Sciences/National Academy Press; 2008. p. 43-64.

Hall TA. BioEdit: a user-friendly biological sequence alignment editor and analysis program for Windows 95/98/NT. Nucleic Acids Symp Ser. 1999; 41: 95-8.

Hastriter M, Lawyer P. Disease vector ecology profile Colombia. Washington (DC): Armed Forces Pest Management Board; 1998. 80 pp.

Hoberg E, Kutz S, Nagy J, Jenkins E, Elkin B, Branigan M. Protostrongylus stilesi (Nematoda: Protostrongylidae): ecological isolation and putative host-switching between Dallaposis sheep and muskoxen in a contact zone. Comp Parasitol. 2002; 69(1): 1-9.

Holmes E. Evolutionary history and phylogeography of human viruses. Annu Rev Microbiol. 2008; 62: 307-28.

Holmes E. The evolutionary genetics of emerging viruses. Ann Rev Ecol Evol Syst. 2009; 40: 353-72.

Hoshino K, Isawa H, Tsuda Y, Yano K, Sasaki T, Yuda M, et al. Genetic characterization of a new insect flavivirus isolated from Culex pipiens mosquito in Japan. Virology. 2007; 359(2): 405-14.

Hoyos R, Usme J, Gallego JC. Viral evolutionary ecology: conceptual basis of a new scientific approach for understanding viral emergence. In: Nuno L, editor. Epidemiology - Current perspectives on research and practice. Rijeka: Intech; 2012. p. 119-27.

Hoyos-López R, Roman SR, Castaño JC, Gallego-Gómez JC. DNA barcode for typing of inmature mosquitoes from Armenia and Circasia (Quindio, Colombia). Rev Colomb Entomol. 2015d; 41(2): 218-27.

Hoyos-López R, Soto SU, Rúa-Uribe G, Gallego-Gómez JC. Molecular identification of Saint Louis encephalitis virus genotype IV in Colombia. Mem Inst Oswaldo Cruz. 2015b; 110(6): 719-25.

Hoyos-López R, Suaza J, Tenorio A, Uribe S, Gallego-Gómez J. Molecular detection of eastern equine encephalitis virus in mosquitoes from La Pintada (Antioquia). Rev MVZ Córdoba. 2015c; 20(3): 4800-6.

Hoyos-López R, Uribe S, Gallego-Gómez JC. Evolutionary relationships of West Nile virus detected in mosquitoes from a migratory bird zone of Colombian Caribbean. Virol J. 2015a; 12: 80 .

Huanyu W, Haiyan W, Shihong F, Guifang L, Hong L, Xiaoyan G, et al. Isolation and identification of a distinct strain of Culex Flavivirus from mosquitoes collected in Mainland, China. Virol J. 2012; 9: 73.

Jaramillo M, Peña J, Berrocal L, Komar N, González M, Ponce C, et al. Vigilancia centinela para el virus del Oeste del Nilo en culícidos y aves domésticas en el departamento de Córdoba. Rev MVZ Córdoba. 2005; 10(2): 633-8.

Kent R, Crabtree M, Miller B. Transmission of West Nile virus by $\mathrm{Cu}$ lex quinquefasciatus say infected with Culex Flavivirus Izabal. PLoS Negl Trop Dis. 2010; 4(5): e671.

Kim D, Guzman H, Bueno R, Dennett J, Auguste A, Carrington C, et al. Characterization of Culex Flavivirus (Flaviviridae) strains isolated from mosquitoes in the United States and Trinidad. Virology. 2009; 386(1): 154-9.
Kramer L, Chandler L. Phylogenetic analysis of the envelope gene of St. Louis encephalitis virus. Arch Virol. 2001; 146(12): 2341-55.

Kumar NP, Rajavel AR, Natarajan R, Jambulingam P. DNA barcodes can distinguish species of Indian mosquitoes (Diptera: Culicidae). J Med Entomol. 2007; 44(1): 1-7.

Lane J, Cerqueira N. Os sabetíneos da America (Diptera: Culicidae). Arq Zool. 1942; 3: 473-82.

Lane J. Neotropical Culicidae. Vols I-II. São Paulo: Universidade de São Paulo; 1953. 1112 pp.

Laurito M, de Oliveira TMP, Almirón WR, Sallum MAM. COI barcode versus morphological identification of Culex (Culex) (Diptera: $\mathrm{Cu}-$ licidae) species: a case study using samples from Argentina and Brazil. Mem Inst Oswaldo Cruz. 2013; 108(Suppl. 1): 110-22.

Machado D, Mondini A, dos Santos S, Santana V, Yonamine P, Chiaravalloti $\mathrm{F}$, et al. First identification of Culex flavivirus (Flaviviridae) in Brazil. Intervirology. 2012; 55(6): 475-83.

Mattar S, Edwards E, Laguado J, González M, Alvarez J, Komar N. West Nile virus antibodies in Colombian horses. Emerg Infect Dis. 2005a; 11(9): 149-50.

Mattar S, Komar N, Young G, Alvarez J, Gonzalez M. Seroconversion for West Nile and St. Louis encephalitis viruses among sentinel horses in Colombia. Mem Inst Oswaldo Cruz. 2011; 106(8): 976-9.

Mattar S, Parra M, Torres J. Limitaciones para el serodiagnóstico del virus del Nilo del oeste en zonas endémicas con co-circulación de Flavivirus en el Caribe colombiano. Colomb Med. 2005b; 36(3): 179-85.

Méndez F, Barreto M, Arias J, Rengifo J, Muñoz J, Burbano M, et al. Human and mosquito infections by dengue viruses during and after epidemics in a dengue-endemic region of Colombia. Am J Trop Med Hyg. 2006; 74(4): 678-83.

Méndez J, Gerzaín R, Bernal M, Calvache D, Boshell J. Detección molecular del virus de la fiebre amarilla en muestras de suero de casos fatales humanos y en cerebros de ratón. Biomedica. 2003; 23(2): 232-8.

Méndez J, Usme-Ciro J, Domingo C, Rey G, Sánchez J, Tenorio A, et al. Phylogenetic reconstruction of dengue virus type 2 in Colombia. Virol J. 2012; 9: 64

Méndez W, Liria J, Navarro J, García C, Freier J, Salas R, et al. Spatial dispersion of adult mosquitoes (Diptera: Culicidae) in a sylvatic focus of Venezuelan equine encephalitis virus. J Med Entomol. 2001; 38(6): 813-21.

Morales A. Distribución geográfica, horizontal y vertical de Haemagogus (Díptera: Culicidae) de Colombia. Rev Acad Cien Fls Exact Nat. 1968; 13: 267-72.

Morales-Betoulle M, Monzón M, Sosa S, Panella N, López M, Cordón-Rosales C, et al. Culex flavivirus isolates from mosquitoes in Guatemala. J Med Entomol. 2008; 45(6): 1187-90.

Múnera G, Méndez J, Rey G. Importancia de los análisis serológicos, moleculares y virológicos en la vigilancia de la fiebre amarilla en Colombia, 2006-2008. Biomedica. 2010; 30(3): 345-52.

Naicker P. The impact of climate change and other factors on zoonotic diseases. Arch Clin Microbiol. 2011; 2(4): 1-6.

Nei M, Kumar S. Molecular evolution and phylogenetics. New York: Oxford University Press; 2000. 800 pp.

Newman C, Cerutti F, Anderson T, Hamer G, Walker E, Kitron U, et al. Culex flavivirus and West Nile virus mosquito coinfection and positive ecological association in Chicago, United States. Vector Borne Zoonotic Dis. 2011; 11(8): 1099-105.

Nunes M, Silva S, Carvalho V, Vasconcelos J, da Silva D, Oliveira L, et al. Emergence of a new insect-restrictive viruses in the Amazon Region. Genome Announc. 2015; 3(2): e00131-5. 
Olival KJ, Daszak P. The ecology of emerging neurotropic viruses. J Neurovirol. 2005; 11(5): 441-6.

Osorio J, Ciuoderis K, Lopera J, Piedrahita L, Murphy D, Levasseur $\mathrm{J}$, et al. Characterization of West Nile viruses isolated from captive American flamingoes (Phoenicopterous ruber) in Medellin, Colombia. Am J Trop Med Hyg. 2012; 87(3): 565-72.

Parra-Henao G, Suárez L. Mosquitos (Diptera: Culicidae) vectores potenciales de arbovirus en la región de Urabá, noroccidente de Colombia. Biomedica. 2012; 32(2): 252-62.

Pecor JE, Mallampalli VL, Harbach RE, Peyton EL. Catalog and illustrated review of the subgenus Melanoconion of Culex (Diptera: Culicidae). Contrib Am Entomol Inst. 1992; 27(2): 1-228.

Poveda G, Graham N, Epstein P, Rojas W, Quiñones M, Velez I. Climate and ENSO variability associated with vector-borne diseases in Colombia. In: Diaz H, Markgraf V, editors. El Niño and the southern oscillation multiscale variability and global and regional impacts. New York: Cambridge University Press; 2000. p. 183-204.

Poveda G, Jaramillo A, Gil M, Quiceno N, Mantilla R. Seasonality in ENSO-related precipitation, river discharges, soil moisture, and vegetation index in Colombia. Water Resour Res. 2001; 37(8): 2169-78.

Prías-Landínez E, Bernal C, Morales A. Isolation of Ilheus virus from man in Colombia. Am J Trop Med Hyg. 1968; 17(1): 112-4.

Rivas F, Diaz A, Cardenas M, Daza E, Bruzon L, Alcala A, et al. Epidemic Venezuelan equine encephalitis in La Guajira, Colombia, 1995. J infect Dis. 1995; 175(4): 828-32.

Roca-Garcia M. Isolation of three neurotropic viruses from forest mosquitoes in eastern Colombia. J Infect Dis. 1944; 75(2): 160-9.

Rojas X, Sierra-Correa P, editors. Plan integral de Manejo del Distrito de Manejo Integrado (DMI) bahía de Cispatá - La Balsa Tinajones y sectores aledaños del delta estuarino del río Sinú, departamento de Córdoba. Santa Marta, Magdalena (Colombia): Corporación Autónoma Regional de los Valles del Sinú y del San Jorge (CVS) e Instituto de Investigaciones Marinas y Costeras (INVEMAR); 2010. 76 pp.

Rojas-Álvarez D. Situación de la fiebre amarilla en Colombia. Informe final de 2007. Inf Quinc Epidemiol Nal. 2008; 13: 97-108.

Rozo-López P, Mengual X. Mosquito species (Diptera, Culicidae) in three ecosystems from the Colombian Andes: identification through DNA barcoding and adult morphology. Zookeys. 2015; 513: 29-64.

Ruiz-Guerra C, Johnston-González R, Castillo L, CifuentesSarmiento Y, Eusse D, Estela F. Atlas de aves playeras y otras aves acuáticas en la Costa Caribe Colombiana. Cali, Valle del Cauca (Colombia): Asociación Calidris; 2008. 77 pp.
Saitou N, Nei M. The neighbor-joining method: a new method for reconstructing phylogenetic trees. Mol Biol Evol. 1987; 4(4): 406-25.

Sánchez-Seco M, Rosario D, Domingo C, Hernández L, Valdés K, Guzmán M, et al. Generic RT-nested-PCR for detection of flaviviruses using degenerated primers and internal control followed by sequencing for specific identification. J Virol Methods. 2005; 126(1-2): 101-9.

Sánchez-Seco M, Rosario D, Quiroz E, Guzmán G, Tenorio A. A generic nested-RT-PCR followed by sequencing for detection and identification of members of the Alphavirus genus. J Virol Methods. 2001; 95(1-2): 153-61.

SanMartín C, Trapido H, Barreto P, Lesmes C. Isolation of Venezuelan and eastern equine encephalomyelitis from sentinel hamsters exposed in pacific lowlands in Colombia. Am J Trop Med Hyg. 1971; 20(3): 469-73.

Sanmartin-Barbieri C, Osorno-Mesa E. Human epidemic in Colombia caused by the Venezuelan equine encephalomyielitis virus. Am J Trop Med Hyg. 1954; 3(2): 283-91.

Singh S. Viral infections and global change. New Jersey: Blackwell press; 2013. $660 \mathrm{pp}$.

Sirivanakarn S. A review of the systematics and proposed scheme of internal classification of the new world subgenus Melanoconion of Culex (Diptera: Culicidae). Mosq Syst. 1982; 14: 265-332.

Soriano-Lleras A, Figueroa L. Aislamiento de un virus de caballo atacado con "peste loca". Bol Inst Nac Hig. 1942; 7: 1-8.

Tamura K, Stecher G, Peterson D, Peterson N, Filipski A, Kumar S. MEGA6: molecular evolutionary genetics analysis version 6.0. Mol Biol Evol. 2013; 30(12): 2725-9.

Vasilakis N, Forrester NL, Palacios G, Nasar F, Savji N, Rossi SL, et al. Negevirus: a proposed new taxon of insect-specific viruses with wide geographic distribution. J Virol. 2013; 87(5): 2475-88.

Walter S, Hildreth S, Beaty B. Estimation of infection rates in population of organisms using pools of variable size. Am J Epidemiol. 1980; 112(1): 124-8.

Weaver S, Ferro C, Barrera R, Boshell J, Navarro J. Venezuelan equine encephalitis. Annu Rev Entomol. 2004; 49: 141-74.

Weaver S, Reisen W. Present and future arboviral threats. Antiviral Res. 2010; 85(2): 328-45.

Weaver S, Salas R, Rico-Hesse R, Ludwing G, Steven M, Boshell J, et al. Re-emergence of epidemic Venezuelan equine encephalomyelitis in South America. Lancet. 1996; 348(9025): 436-40.

Weaver SC. Host range, amplification and arboviral disease emergence. Arch Virol Suppl. 2005; 19: 33-44. 